\title{
WORKING UNIVERSITY STUDENTS IN RIAU ARCHIPELAGO: DUAL ROLE AND DEPRESSION
}

\author{
Nurul Retno Nurwulan \\ Sampoerna University, Indonesia \\ E-mail:nurul.numulan@sampoernauniversity.ac.id
}

\section{Gjergji Selamaj}

University Ismail Qemali, Indonesia

E-mail:gjergii.selamaj147@gmail.com

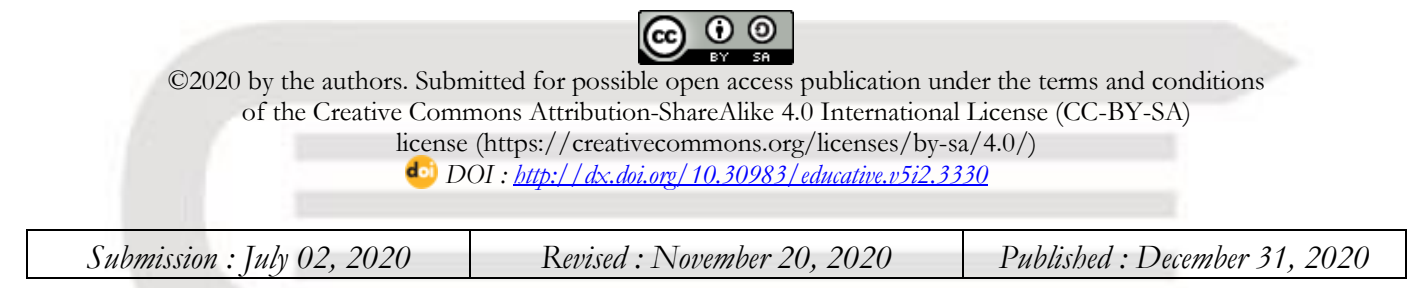

\begin{abstract}
University students working and studying at the same time for various reasons. The aim of the study is to review the impact of students' dual role as students and workers on the depression rate of working university students in Batam, Indonesia. A comprehensive review of the literature revealed that working while studying does not necessarily affect students' academic performance. However, depression is the most common health problem in university students. However, working students tend to have higher depression rate than non-working students. Depression in students may be the cause of the high dropout rate in Batam. It is important to administer depression-prevention intervention as early as possible, since the first- and second-year students are the most likely to get depressed.
\end{abstract}

Keywords: depression, dropout, dual role, intervention, working students.

\section{Abstrak}

Beragam alasan melatarbelakangi mahasiswa bekerja selama berkuliah. Penelitian ini mengulas dampak peran ganda sebagai mahasiswa dan pekerja kecenderungan depresi pada mahasiswa bekerja di Batam, Indonesia. Ulasan komprehensif dari literatur dan observasi langsung menunjukkean bahwa bekerja sambil berkuliah tidak mempengarubi kinerja akademis mahasiswa. Meskipun demikian, mahasiswa bekerja cenderung memiliki tingkat depresi yang lebih tinggi daripada mahasiswa yang tidak bekerja. Depresi pada mahasiswa dapat menjadi penyebab tingginya tingkat dropout di Batam. Melakukan intervensi pencegahan depresi pada mahasiswa sedini mungkin merupakan hal yang sangat penting dikarenakan mahasiswa tingkat pertama dan kedua adalah yang paling rentan terhadap depresi.

Kata Kunci: depresi, dropout, intervensi, mahasiswa bekerja, peran ganda.

\section{Introduction}

Nowadays, a bachelor's degree is a mandatory requirement to apply for a decent job. Educational background is one of an important factor to decide the salary of an employee. Well-educated employees often get higher salaries than less-educated ones, regardless of their skills and experiences. However, higher education is still a luxury for students from a less fortunate background.
This condition forces students to work while studying to ensure they could pay the tuition fees, buy school supplies, and even to provide daily needs for their family.

In Indonesia, the government supports students from low economic families with a scholarship to ensure the students could get a proper education. Since 2010, the Indonesian government assists students from low 
economic backgrounds to continue the education in the university through the "Bidik Misi" program. ${ }^{1}$ The scholarship will ensure students with excellent academic achievement during high school to get at least a bachelor's degree. The assisted students will receive tuition fees and monthly living allowances until they finish their education. However, the scholarship program is only for students with high academic achievement studying in a reputable university. Thus, students with ordinary academic performance will need to figure out by themselves how to pay the tuition fees and other needs. Working parttime after class is a common practice for university students.

As a free trade zone island, Batam is a popular destination for people from all over Indonesia who are urgently trying to find a job. Most of them are high school graduates and can only end up as untrained workers. Many full-time workers enroll in university to improve their skills to remain hired or find better job opportunities. They work in the daytime and study in the evening. Although the number of student enrollment in universities is quite high, the dropout ratio of university students in Riau Archipelago is the second highest in Indonesia $(7.5 \%)$. Whereas, the average dropout ratio of university students in Indonesia is only $2.8 \%{ }^{2}$ The high dropout ratio in Riau Archipelago, especially in Batam island, might happens because most of the students are also workers.

The effect of working on university students' academic performance is inconclusive, as there are both positive

1 Ristekdikti, Bidikmisi Requirements 2019. (Kementrian Riset, Teknologi, dan Pendidikan Tinggi Republik Indonesia, Indonesia, 2019).

${ }^{2}$ Ristekdikti, Higher Education Statistical Year Book. (Kementrian Riset, Teknologi, dan Pendidikan Tinggi Republik Indonesia, Indonesia, 2017). effects, ${ }^{3,4}$ negative effects, ${ }^{5,6}$ and no effect at all. ${ }^{7,8,9,10}$ Working during college studies has a positive impactt on future careers. Conversely, it might affect the drop out ratio and duration of studies. ${ }^{11}$ Some studies found that the effect of working on university students depends on their motivations and understanding of the impact of their work on their academic performance or the impact of their study on their careers. ${ }^{9,10}$

Although there have been various studies on the effect of working during university studies, to the knowledge of the authors, no previous studies have examined the root causes of the dropout of students from the university to working during university studies in Indonesia. With regard to this, the author aimed to explore the possibility to utilize the depression

${ }^{3}$ Muluk S. Part-time Job and Students' Academic Achievement. Jurnal Ilmiah Peuradeun, 5.3, (2017), p. 361372.

${ }^{4}$ Almeida, D. J., et al. How Relevant is Grit? The Importance of Social Capital in First-Generation College Students' Academic Success. Journal of College Student Retention: Research, Theory \& Practice, (2019).

${ }^{5}$ Broton, K. M., et al. Working for College: The Causal Impacts of Financial Grants on Undergraduate Employment. Educational Evaluation and Policy Analysis, 38.3, (2016), p. 477-494.

${ }^{6}$ Tessema, M. T., et al. Does Part-Time Job Affect College Students' Satisfaction and Academic Performance (GPA)? The Case of a Mid-Sized Public University. International Journal of Business Administration, 5.2, (2014).

${ }^{7}$ Simón, H., et al. Analysis of University Student Employment and its Impact on Academic Performance. Electronic Journal of Research in Educational Psychology, 15.2, (2017), p.281-306.

${ }^{8}$ Smith, R. A., and Schoffstall, D.G. Employment Impact on Hospitality and Tourism Students' Academic Journey: the HBCU Students' Perspective. Journal of Teaching in Travel \& Tourism, 20.2, (2020), p.105-120.

${ }^{9}$ Mounsey, R., et al. Working and Non-Working University Students: Anxiety, Depression, and Grade Point Average. College Student Journal, 47.2, (2013), 379389.

${ }_{10}$ Rijavec, M., et al. Working Part-Time During Studies: The Role of Flow in Students' Well-Being and Academic Achievement. Croatian Journal of Education, 19.3, (2017). p.157-175.

11 Tur-Sinai, A., et al. The True Effect of Students' Employment on the Duration of Studies. Applied Economics, 49.33, (2017), p.3328-3340. 
measurements to evaluate the cognitive workload of working university students that might potentially contribute to the dropout ratio, as depression is one of the most common health issues for students. ${ }^{12}$ The number of depressed university students increases steadily ${ }^{13}$ and it has been related to poorer academic accomplishments, ${ }^{14,15,16,17}$ relationship instability, ${ }^{14,17}$ and suicidal thoughts and attempts. ${ }^{13,18,19,20}$

The purpose of this study was to comprehensively review: 1) the effect of working during university studies, 2) the depression measurements that have been used on university students, and 3) the depressionprevention intervention methods.

\section{Methods}

Peer-reviewed studies from PsycINFO, Medline, PubMed, and BioMed Central databases which were reviewed comprehensively. The articles reported about the research related to depression and working university students which is published from 2000 to 2019. The keywords used in the searches were working university students, working students, student employment, university students, college students, depression, and depressive symptoms. Inclusion criteria in the review were 1) the subjects of the study were working university students; 2) the study reported depression measurements on university students; 3 ) the study was reported in English.

A total of 59 papers were retrieved after reviewing the titles, abstracts, and reference lists for relevant papers. After careful evaluation of the 59 papers, 31 additional papers were excluded as the consequences of the following justifications: the research sample was non-university students (25 papers) and the studies did not measure the depression or cognitive workload of university students (6 papers). Finally, remaining 28 papers have been included and analyzed.

\section{Findings and Discussion \\ Findings}

Only 28 out of a total of 1107 papers met all the inclusion criteria; only 28 studies satisfied all the inclusion criteria: the research sample was working undergraduate students (18 papers) and the research reported depression measurements on university students (10 papers).

\section{Working University Students}

There is a growing trend of working during university studies. Past studies have shown contradictory results of the effect of working on academic performance. 
A study by Dundes and Mark ${ }^{3}$ showed that students who worked for 10-19 hours per week were better than all other students, working and non-working, in terms of academic performance. This happened because they could balance employment and study optimally. The requirements from work and study forced the students to establish a more structured life, which cannot be achieved by the non-working students. The working university students also mostly pay the tuition fees by themselves and thus, they feel more responsibility in giving their best in their study since they know how difficult it is to earn money. Although working university students could establish a more structured life, the workloads from both work and study will increase stress and reduce the time for having free time to socialize.

Another past study showed that working made students have a more focused and structured life because the students are demanded to manage time. ${ }^{4}$ The working students also learned to enhance selfconfidence in working with people. Thus, working during university studies helped them in preparing for their future career. Despite its benefits, working students have less free time, sleep time, and less to no time to socialize with friends.

On the contrary to popular beliefs, working students have higher academic satisfaction and higher GPA than nonworking students. However, that only applied to students who worked less than 10 hours per week, students who worked for more than 11 hours per week seemed to have poor satisfaction and GPA. ${ }^{6}$ The academic demands from the university could be overwhelming for full-time working students considering they need to attend the classes, do the assignments, do the exams, etc. when they also need to finish the working assignments from the office. Working could indeed increase confidence, skill development, and financial gains for students in general. Yet, those who could not balance the demands of paid-work and study are more likely to drop out before completing their degree. ${ }^{5}$

Some other past studies found that working during university studies does not affect academic performance, ${ }^{7,8,9,10}$ Error! Bookmark not defined. although working students' perceived working has a negative impact on academic performance.Error! Bookmark not defined. However, there was no difference in well-being, burnout, and GPA of working students compared to non-working students. ${ }^{10}$ This could happen because the academic performance of the students depends on their ability and motivation..$^{8,10}$ However, working while studying has impacted their involvement socially.

Past studies regarding the impact of working while studying showed inconsistency and even contradiction that may happen due to the differences between methodological settings. The characteristics of the students, the university environment, and the nature of the work may greatly contribute to the contradictory findings. ${ }^{11}$

University Students and Depression

Depression is the most common health issues for university students. It has become increasingly prevalent and might become the biggest barrier to doing well in school. The rates of depression for university students are higher than for the general population. ${ }^{12}$ The transition from high school to university could be stressful for some students since they must manage everything by themselves and will not have their parents to depend on. The freshman and sophomore students are reported to be more depressed ${ }^{141821}$ with female students are more likely to have moderate to severe

21 Larcombe, W., et al. Prevalence and SocioDemographic Correlates of Psychological Distress Among Students at an Australian University. Studies in Higher Education, 41.6, (2016), p.1074-1091. 
depression. ${ }^{1921,22,23}$ More than one-third of the students feel they have a lack of time, lack of confidentiality, no one will understand their problems, and their problems are not important. $^{14}$ A past study showed that students' attachment anxiety contributes to the loneliness that resulted in depression due to social self-efficacy. ${ }^{24}$ About half of the students are reported that they cannot share with someone else ${ }^{17}$ and chose to not ask for medical assistance, ${ }^{20}$ because they think their fellow students would respect them less. ${ }^{19}$

The depression on university students may have an impact on academic performance, dropout rates, and professional development after graduation. ${ }^{22,} 25$ The academic stress that the students faced creates more depression than mental issues. ${ }^{17}$ Students who are satisfied with their academic performance are less likely to get depressed ${ }^{21}$ and students with financial problems are at higher risk for depression. ${ }^{15,26,27}$ Students with depression, especially working students, tend to show the depression symptom such as

22 Pacheco, J. P., et al. Mental Health Problems Among Medical Students in Brazil: A Systematic Review and Meta-Analysis. The Revista Brasileira de Psiquatria, 39.4, (2017), p.2223.

23 Mahmoud, J. S. R., et al. The Relationship Among Young Adult College Students' Depression, Anxiety, Stress, Demographics, Life Satisfaction, and Coping Styles. Issues in Mental Health Nursing, 33, (2012), p.149-156.

${ }^{24}$ Moeller, R. W., and Seehus, M. Loneliness as a Mediator for College Students' Social Skills and Experiences of Depression and Anxiety. Journal of Adolescence, 73 (2019), p.1-13.

25 Portoghese, I., et al. Measuring Burnout Among University Students: Factorial Validity, Invariance, and Latent Profiles of the Italian Version of the Maslach Burnout Inventory Student Survey (MBI-SS). Frontiers in Psychology, 9, (2018), p.2105.

${ }^{26}$ Khawaja, N. G., and Duncanson, K. Using the University Student Depression Inventory to Investigate the Effect of Demographic Variables on Students' Depression. Australian Journal of Guidance and Counseling, 18.2, (2018), p. 195-209.

${ }^{27}$ Eisenberg, D., et al. Prevalence and Correlates of Depression, Anxiety, and Suicidality Among University Students. American Journal of Orthopsychiatry, (2017), p. 534-542. biting their nails, isolate themselves from others, and have digestion problems. ${ }^{16}$

It is necessary for the university to assess the mental health of its students about the increasing number of students with depression and to incorporate recovery services to help students cope with depression, ${ }^{1316}$ such as by establishing a pleasant atmosphere between lecturers and students. The high prevalence of depression could also reduce campus connectivity or social connectivity within the university. ${ }^{28}$ Another past research showed that daily physical activity has been shown to help students cope with depression. ${ }^{17}$

\section{Depression Measurements}

There are various measurements for depression and past studies used the following measurements for university students.

First, Beck Depression Inventory (BDI) is a validated instrument to measure depressive symptoms. It contains a list of 21 questions that are most widely used to measure the severity of depression. The BDI has been developed in various forms, including several computerized forms, a card form, the 13-item short form, and the more recent BDI-II. It takes approximately 10 minutes to complete the BDI, but to properly understand the questions, subjects require a fifth-sixth grade reading level. The BDI shows strong internal consistency for psychiatric and non-psychiatric populations, with alpha coefficients of 0.86 and 0.81 , respectively. However, the BDI tends to overestimate true depression, because the questions are being rooted in a psychodynamic perspective. ${ }^{14}$

Second, Patient Health Questionnaire (PHQ) consists of 9-validated questions that have been used in a wide variety of

${ }^{28}$ Pidgeon, A. M., et al. Psychosocial Moderators of Perceived Stress, Anxiety and Depression in University Students: An International Study. Open Journal of Social Sciences, 2, (2014), p. 23-31. 
populations to assess depressive symptoms. The PHQ-9 is a self-administered variant of the PRIME-MD diagnostic method for various mental disorders. The PHQ-9 has been validated for primary care. It includes the depression module, which scores "0" (not at all) to "3" (almost every day) for each of the nine DSM-IV criteria. It is not a depression screening tool, but it is used to track depression severity and response to treatment. It also correlates well with clinician depression diagnosis using the basic criteria of the Diagnostic and Statistical Manual of Psychiatric Disorders (DSM-IV). ${ }^{192027}$

Third, the Hospital Anxiety and Depression Scale (HADS) is a list of 14 questions, including 7 anxiety-related questions and 7 other depression-related questions. Each item on the list is scored between 0-3 and a person can score between 0 and 21 for either depression or anxiety. ${ }^{15}$ The HADS was developed to provide a simple but reliable medical practice method for use. In its title, the word 'hospital' means that it is only applicable in such an area, although several kinds of past research carried out worldwide have shown that it is valid when used in community settings and primary medical practice. It should be emphasized that scales for self-assessment are only appropriate for screening purposes; definitive diagnosis must be based on the clinical evaluation process.

Fourth, centered on the three-phase model, which are alarm, resistance, and exhaustion, the Stress Symptoms Inventory (SSI) includes a list of 41 psychophysiological symptoms indicative of chronic stress. Each person responds to stress differently. Events and activities that cause stress, as well as the symptoms that are conveyed, are very personal. As a result of too much demand and strain, the SSI measures the psychological and physical symptoms that a person can experience. Average and standard deviation (SD) can be used as the basis of the classification into high, medium, and low levels of chronic stress. A high level is known to be greater than two or three SD; less than one SD is the medium level, and less than two or three SD is the low level. ${ }^{16}$

Fifth, it has been shown that the Depression Anxiety Stress Scale (DASS) is an accurate indicator of the aspects of depression, anxiety, and stress separately, but also draws into a more general psychological distress component. There are two types available for the DASS: the DASS-21 and the DASS-42. The DASS is a tool for self-reporting, and to administer or score it, no special skills are needed. The DASS-21 is a short version of the DASS-42 that measures the negative states of three mental health conditions: depression, anxiety, and stress. ${ }^{21}$ It was developed by the University of New South Wales, Australia with a 7-item subscale, the DASS-21 measures each of the three variables, asking participants to focus on the past week's emotions, feelings, and actions. The answers to each item range from 0 (not at all applicable to me to 3 (very applicable to me). The scores for each scale are multiplied by two, as the DASS-21 is a simplified version of the complete DASS -42 . The three subscales have normal scores of less than 9 for depression, 7 for anxiety, and 14 for stress. ${ }^{1323}$

Sixth, University Student Depression Inventory (USDI) is a list of 30 self-report questions to assess depressive symptoms in university students. It is made up of three variables: lethargy, cognitive-emotional, and academic motivation. ${ }^{26}$ The lethargy factor consists of nine items that included exhaustion, attention problems, and task efficiency items. The second (CognitiveEmotional) component consists of 14 items that included items relating to low selfefficacy, depression, and worthlessness. Academic motivation, the third element, consists of seven items that included motivational and research task items. 
Seventh, the Perceived Stress Scale (PSS) is a 10-item question to measure perceptions of stress. It is the psychological method most commonly used to measure stress perception. It is a measure of the degree to which circumstances are assessed as stressful in one's life. Items were built to describe the way respondents find their lives to be uncertain, and overwhelming. A variety of clear questions about current levels of experienced stress are also included in the scale. The questions are simple and it is easy to understand the reaction choices. Also, the problems are of a general nature and are thus largely free from bias to any subpopulation. The PSS questions are about emotions and reflections over the past month. Respondents are asked in each case how much they feel a certain way. To determine a global measure of perceived stress, the total number of items on the scale is summed up with higher scores indicating higher levels of perceived stress. ${ }^{28}$

Eight, the Campus Connectedness Scale (CCS) is a 14-item question to measure the perception of belongingness on the university campus. The 14 -items are summed with higher scores indicative of higher levels of campus connectedness. ${ }^{28}$ In the lives of students, social interaction and its relationship with anxiety, self-esteem, and social identity are correlated. Social connectivity is negatively linked to anxiety and may affect more than social support or mutual self-esteem to anxiety. In contrast to low cohesion conditions, students with high connectedness have higher social identification. In either condition, students with low connectedness will show no difference.

Ninth, the Multidimensional Scale of Perceived Social Support (MSPSS) is a 12-item query to assess how people through families, friends, and significant others view their global social support system. The MSPSS is a widely used scale and has been updated in multicultural settings and diverse cultures across several studies. It has a framework of three variables that weigh family, friends, and significant others. Social support from these communities is very meaningful and could provide a feeling that support is reliable and accessible. The seven-point Likert scale ranging from 1 (very strongly disagree) to 7 (very strongly agree) is used for each item of the questions. By summing the responses to the 12 items with higher values suggesting higher levels of perceived social support, a global measure of perceived social support is obtained. ${ }^{28}$ A higher score of the MSPSS indicates greater social support perceived by an individual.

Tenth, Brief Cope Inventory (BCI) is a 28-item question to measure the adaptive and maladaptive coping style. It is the shorter version of the COPE inventory with 60-item questions. Responses on each item vary from 0 (I usually do not do this at all) to 3 (I usually do this a lot). It is designed to determine effective and unsuccessful ways to deal with a traumatic event in life. Coping is an attempt to mitigate discomfort associated with adverse life experiences. The BCI can also be used to assess the coping mechanism, how patients respond to a serious diagnosis in health-care settings. The assessment is mainly about how a wide variety of adversity is coped with by another, including a diagnosis of cancer, heart disease, accidents, attacks, natural disasters, and financial stress. Strategies such as acceptance, preparation, and constructive reframing are used in adaptive coping. Whereas, maladaptive coping strategies are related to denial, self-blaming, and substance use..$^{23}$ There are two coping strategies namely avoidant coping and approach coping. The subscales of denial, drug use, venting, mental disengagement, self-distraction, and self-blame describe avoidant coping. For people with physical illnesses, evasive coping is linked to poorer physical fitness. Avoidant coping is less effective in handling fear relative to approach 
coping. Approach coping is characterized by successful coping subscales, constructive reframing, preparation, recognition, mental help finding, and intelligence support seeking. More beneficial approaches to stress, including adaptive practical change, improved physical health performance, and more stable emotional reaction, are consistent with approach coping.

Eleventh, Brief Multidimensional Students' Life Satisfaction Scale (BMSLSS) is a 40-item questionnaire that was derived from the 7-point Delighted-Terrible Scale (DTS). According to the scale, $1=$ awful, $2=$ unhappy, $3=$ mostly dissatisfied, $4=$ mixed (about evenly satisfied and dissatisfied), $5=$ mostly satisfied, $6=$ pleased, and $7=$ delighted. Higher ratings reflect greater satisfaction with life. ${ }^{23}$ The BMSLSS was developed specifically to measure the life satisfaction of children and adolescents in the United States, and Caucasians and African Americans were the participants. The BMSLSS provides five elements on the fulfillment of five main aspects of life: family life satisfaction, relationship satisfaction, school experience satisfaction, self-satisfaction, and living environment satisfaction. On a 7-point Likert-type scale, ranging from $1=$ awful to 7 $=$ delighted, the five main aspects of life are ranked. The BMSLSS has shown reasonable internal reliability for accuracy. It provides proof of construct validity with substantial associations as anticipated to youth optimism and youth symptom intensity indicators.

\section{Depression Prevention Intervention}

There are several different types of depression-prevention interventions that have been conducted in past studies. Several popular intervention methods are cognitivebehavioral counseling, interpersonal-process therapy, computer training, personal input by recommendations for mailed action, and training for exercise and stress. ${ }^{17,29}$ However, none of the past studies evaluated the effect of taking depression medication in university students. ${ }^{29}$ The interventions for depressionprevention could be carried out individually, in a group, or mixed individual-group format with the time frame for intervention evaluation could be either immediately, postintervention only, or longitudinal study for more than 3 years. ${ }^{29}$ To see the effectiveness of the interventions for depressionprevention, it is suggested to assess the depression intensity of the students periodically. The university should assign a counselor to assess the depression of all students before the intervention, during the intervention, and post-intervention. The results of the assessment could be used to come up with strategies on how to reduce the depression level of the students to enhance students' performance for both working students and non-working students.

\section{Discussion}

Batam is the biggest island in Riau Archipelago, Indonesia. Its strategic location in the Indonesia-Malaysia-Singapore triangle growth made the island the most popular destination for the youths from all over Indonesia to find a job. Most of them are only high school graduates and ended up as untrained workers. With the hope of getting a better career and future, they enrolled in the university as full-time students. However, life at the university is not as easy as they expected. It is not that simple to get a degree, especially when they need to work full-time at the same time. Many students decided to quit school because they could not keep up the dual roles as employees and students. The dropout rate in Riau Archipelago is 7.5\%,

${ }^{29}$ Buchanan, J. L. Prevention of Depression in the College Student Population: A Review of the Literature. Archives of Psychiatric Nursing, 26.1, (2012), p.21-42. 
which is the second highest in Indonesia after Bengkulu province. $^{2}$

In this study, we observed 3 private universities in the city center of Batam from January to May 2019. Most classes in these universities are evening classes. Only 1 university we observed offers both morning and evening classes. In other cities of Indonesia, the universities mostly offer morning classes for a bachelor's degree. The reason why the universities on Batam island offer evening classes is because the majority of the students are workers. It is an interesting phenomenon that most high school students in Batam prefer to work in factories after graduation rather than pursuing further education in the university. Most university students we interviewed admitted that they decided to enroll in university only to get a better career path in their current jobs. A high school diploma is enough to get a job in the city or even in Singapore and Malaysia since the demands for cheap workers are quite high. However, they need a bachelor's degree if they want to get a promotion or salary increment.

The workers enrolled in the university with a dream to get career advancement. The enthusiasm is normally high in the first year of enrollment. Unfortunately, studying and working at the same time is not easy and many students resigned from the university every semester, regardless of their academic performances. In one of the private universities, the decrease in the number of students every year is up to $30 \%$. At the time of our observation, we interacted with the third-year students who enrolled in the university since the first operation year of the university. According to the third-year students majoring in Industrial Engineering, there were only 7 students lasted up to May 2019 from the initial of 20 students. The data from the academic registry of this university showed that none of the students was expelled because of poor academic performances. The students resigned from the school by themselves or simply never came to the class ever again without any notice.

Past studies have shown that working during studying at the university does not necessarily impact academic performance negatively. The effect of working while studying is inconclusive as some studies showed that working impacted on academic performance positively, ${ }^{3,4}$ some others showed that working impacted on academic performance negatively, ${ }^{5,6}$ and there are also past studies showed that there was no difference between working and non-working students in terms of academic performance. ${ }^{7,8,9,10,}$ Many factors influence the performance of working university students such as the motivation of the students and the support from environments. Students with positive support from the lecturers, friends, and supervisors might show better academic performance.

Although the effect of working on university students is inconclusive, the high dropout rate in working students might be caused by depression as depression is the most common health issue in university students. The assessment of depressive symptoms should be administered as early as possible due to the high prevalence of depression in freshmen and sophomore university students. University life is something new for the workers who just enrolled as students at the university. They might expect that being a student in a private university in Batam would not be difficult and they would have a much better career after they get the diploma. The common perception of Indonesian people is that a private university is not as difficult as a public university. However, each university, regardless of its status as a public or private university, must obey the curriculum requirements of the Ministry of Research and Higher Education. ${ }^{2}$ Thus, even the private 
university life might be too difficult for the workers to keep up with.

We used the Patient Health Questionnaire (PHQ-9) and the Beck Depression Inventory (BDI) to screen the depression level of working students in Batam from February to March 2019. A total of 158 working students participated in the survey. The results of the PHQ-9 showed that 21.52\% of students have mild depression, $17.09 \%$ with moderate depression, $5.69 \%$ with moderately severe depression, and $22.15 \%$ with severe depression. Whereas the BDI showed that $20.88 \%$ have mild mood disturbance, $6.33 \%$ with borderline clinical depression, $8.86 \%$ with moderate depression, and $28.48 \%$ with severe depression. From the survey results, it is evident that the working university students in Batam indeed experience depression, and this could be the cause of why the dropout rate in this city is high.

The differences between reality and expectation might cause depression for working university students and it is important to assess the depressive symptoms in working university students to administer the proper depression-prevention intervention. There are many forms of therapies for university students to avoid depression. Cognitivebehavioral counseling, interpersonal-process therapy, computer training, personal input by recommendations for mailed action, and training for exercise and stress. ${ }^{17,29}$ It is best to administer the interventions above to first-year students (freshmen) and the depressive symptoms screening should be given at least before and after the intervention. A longitudinal study is better than a short-term study due to its ability to monitor the severity of depression in students. Other than that, a longitudinal study could give us more insights even if the prevention-intervention methods fail to lower the depressive symptoms that might result in more dropout rates. The university could adjust the techniques of preventing depression for the students when the depression assessment does not show a satisfactory result. However, it requires more effort and resources than the short-term study.

\section{Conclusion}

The dropout rate in Batam island, Riau Archipelago is the second highest in Indonesia. This might happen because the workers have a lower expectation in the universities in Batam, considering most universities are private universities. It is a common belief for Indonesian people that private universities are easier than public universities. The workers might think that it is easy to get a bachelor's diploma to enhance their future careers from a private university. However because each university must follow the standard of Indonesia's Ministry of Research and Higher Education, the working students might not be able to keep up with the academic demands and they might be easy to get depressed. The assessment of depressive symptoms to the freshmen and sophomore university students is very important before administering the prevention intervention of depression that might result in a high dropout rate. The results of the assessment could be used as a consideration to construct the depression-prevention intervention methods for the students. To measure the effectiveness of the intervention, the university must measure the depression level of the students after the intervention. A longitudinal study would give better results in reducing depression in working university students that in the end might reduce the drop-out rate in Batam island.

In this study, we only observed the private universities in the city center of Batam island. The situations might be different for the universities in the villages of Riau Archipelago. Besides, the results of this study might not be applicable in other cities in 
Indonesia considering the differences in sociocultural conditions. However, the other provinces in Indonesia could use similar approaches to reduce the drop-out rate in university students. Future studies comparing the effectiveness of depression intervention in Batam and other cities in Indonesia might give a better understanding of the impact of depression on students.

\section{References}

Book

Ristekdikti. Higher Education Statistical Year Book. (Kementrian Riset, Teknologi, dan Pendidikan Tinggi Republik Indonesia, Indonesia, 2017).

Ristekdikti, Bidikmisi Requirements 2019.

(Kementrian Riset, Teknologi, dan Pendidikan Tinggi Republik Indonesia, Indonesia, 2019).

\section{Journal}

Almeida, D. J., Byrne, A. M., Smith, R. M., and Ruiz, S. How Relevant is Grit? The Importance of Social Capital in FirstGeneration College Students' Academic Success. Journal of College Student Retention: Research, Theory \& Practice, (2019).

Beiter, R., Nash, R., McCrady, M., Rhoades, D., Linscomb, M., Clarahan, M., and Sammut, S. The Prevalence and Correlates of Depression, Anxiety, and Stress in a Sample of College Students. Journal of Affective Disorder, 173, (2015), p. 90-96.

Broton, K. M., Goldrick-Rab, S., and Benson J. Working for College: The Causal Impacts of Financial Grants on Undergraduate Employment. Educational Evaluation and Policy Analysis, 38.3, (2016), p. 477-494.

Buchanan, J. L. Prevention of Depression in the College Student Population: A Review of the Literature. Archives of Psychiatric Nursing, 26.1, (2012), p. 21-42.
Deb, S., Banu, P. R., Thomas, S., Vardhan, R. V., Rao, P. T., and Khawaja, N. Depression Among Indian University Students and its Association with Perceived University Academic Environment, Living Arrangements and Personal Issues. Asian Journal of Psychiatry, 23, (2016), p. 108-117.

Eisenberg, D., Gollus, S. E., Golberstein, E., and Hefner, J. L. Prevalence and Correlates of Depression, Anxiety, and Suicidality Among University Students. American Journal of Orthopsychiatry, (2017), p. 534-542.

Gao, W., Ping, S., and Liu, X. Gender Differences in Depression, Anxiety, and Stress Among College Students: A Longitudinal Study From China. Journal of Affective Disorders, 263, (2020), p. 292300.

Ibrahim, A. K., Kelly, S. J., Adams, C. E., and Glazebrook, C. A Systematic Review of Studies of Depression Prevalence in University Students. Journal of Psychiatric Research, 47, (2013), p. 391-400.

Khawaja, N. G., and Duncanson, K. Using the University Student Depression Inventory to Investigate the Effect of Demographic Variables on Students' Depression. Australian Journal of Guidance and Counseling, 18.2, (2018), p. 195-209.

Larcombe, W., Finch, S., Sore, R., Murray, C. M., Kentish, S., Mulder, R. A., LeeStecum, P., Baik, C., Tokatlidis, O., and Williams, D. A. Prevalence and SocioDemographic Correlates of Psychological Distress Among Students at an Australian University. Studies in Higher Education, 41.6, (2016), p. $1074-$ 1091.

Mahmoud, J. S. R., Staten, R., Hall, L. A., and Lennie, T. A. The Relationship Among Young Adult College Students' Depression, Anxiety, Stress, Demographics, Life Satisfaction, and 
Coping Styles. Issues in Mental Health

Nursing, 33, (2012), p. 149-156.

Moeller, R. W., and Seehus, M. Loneliness as a

Mediator for College Students' Social

Skills and Experiences of Depression and Anxiety. Journal of Adolescence, 73 (2019), p.1-13.

Mounsey, R., Vandehey, M. A., and Diekhoff,

G. M. Working and Non-Working University Students: Anxiety, Depression, and Grade Point Average. College Student Journal, 47.2, (2013), p.379389.

Muluk S. Part-time Job and Students' Academic Achievement. Jurnal Ilmiah Peuradeun, 5.3, (2017), p.361-372.

Pacheco, J. P., Giacomin, H. T., Tam, W. W., Ribeiro, T. B., Arab, C., Bezzera, I. M., Pinasco, G. C. Mental Health Problems Among Medical Students in Brazil: A Systematic Review and Meta-Analysis.

The Revista Brasileira de Psiquatria, 39.4, (2017), p.2223.

Pidgeon, A. M., McGrath, S., Magya, H. B., Stapleton, P., and Lo, B. C. Y. Psychosocial Moderators of Perceived Stress, Anxiety and Depression in University Students: An International Study. Open Journal of Social Sciences, 2, (2014), p. 23-31.

Portoghese, I., Leiter, M. P., Maslach, C., Galletta, M., Porru, F., D'Alojo, E., Finco, G., and Campagna, M. Measuring Burnout Among University Students: Factorial Validity, Invariance, and Latent Profiles of the Italian Version of the Maslach Burnout Inventory Student Survey (MBI-SS). Frontiers in Psychology, 9, (2018), p.2105.

Pozos-Radillo, E., Preciado-Serrano, L., Plascencia-Campos, A., and RayasServin, K. Chronic Stress and its Association with Psychological, Behavioral and Physiological Variables of Mexican College Students. Advances in Applied Sociology, 5, (2015), p. 299-305.

Rijavec, M., Golub, T. L., Jurcec, L., and Olcar, D. Working Part-Time During Studies: The Role of Flow in Students' Well-Being and Academic Achievement. Croatian Journal of Education, 19.3, (2017). p. 157-175.

Ryan, G., Marley, I., Still, M., Lyons, Z., and Hood, S. Use of Mental-Health Services by Australian Medical Students: A Cross-Sectional Survey. Austrolasian Psycbiatry, 25.4, (2017), p. 407-410.

Schwenk, T. L., Davis, L., and Wimsatt, L. A. Depression, Stigma, and Suicidal Ideation in Medical Students. The Journal of the American Medical Association, 304.11, (2010), p. 1181-1190.

Simón, H., Diaz, C., Manuel, J., Costa, C., and Luis, J. Analysis of University Student Employment and its Impact on Academic Performance. Electronic Journal of Research in Educational Psychology, 15.2, (2017), p. 281-306.

Smith, R. A., and Schoffstall, D.G. Employment Impact on Hospitality and Tourism Students' Academic Journey: the HBCU Students' Perspective. Journal of Teaching in Travel \& Tourism, 20.2, (2020), p. 105-120.

Tessema, M. T., Ready, K. J., and Astani, M. Does Part-Time Job Affect College Students' Satisfaction and Academic Performance (GPA)? The Case of a Mid-Sized Public University. International Journal of Business Administration, 5.2, (2014).

Tjia, J., Givens, J. L., and Shea, J. A. Factors Associated with Under-Treatment of Medical Student Depression. Journal of American College Health, 53.5, (2010), p. 219-224.

Tur-Sinai, A., Romanov, D., and Zussman, N. The True Effect of Students' Employment on 
the Duration of Studies. Applied Economics, 49.33, (2017), p. 3328-3340.

Uchida, C., and Uchida M. Characteristics and Risk Factors for Suicide and Deaths
Among College Students: A 23-Year Serial Prevalence Study of Data From 8.2 Million Japanese College Students. The Journal of Clinical Psychiatry, 78.4, (2017), p.404-412. 